\title{
Fibröz kortikal defekt ve non-ossifiye fibrom
}

\section{Fibrous cortical defect and non-ossifying fibroma}

\author{
Kaan Erler \\ Anadolu Sağlık Merkezi Hastanesi, Ortopedi ve Ortopedik Onkoloji Bölümü, Kocaeli
}

Fibröz kortikal defekt ve non-ossifying fibroma kemiklerde en sık görülen fokal lezyonlardır. ${ }^{[1,2]}$ Benign özellikleri ve tipik radyolojik görünümleri histopatolojik değerlendirmeye gerek bırakmaz ("Lezyonlara dokunmayın!") ${ }^{[3]}$ Bu gerçeğin tersine, radyolojik incelemelerde şaşırtıcı derecede sıklıkla karşımıza çıkması nedeniyle haksız bir ilgiye maruz kalırlar ve konunun ortopedik onkoloji kliniklerine danışılması gerekebilir. ${ }^{4]}$ Bu durumun, lezyonun yaşı ve evrimindeki değişken görünümlere bağlı olduğu düşünülür.

Anahtar sözcükler: fibröz doku tümörleri; kortikal displazi; fibrom, kemikleşici

\footnotetext{
$\mathbf{F}$
} ibröz kortikal defekt (FKD) ve non-ossifying fibroma (NOF) kemiklerin en sık görülen fokal lezyonlarıdır. Yaşamın ilk iki onyılında, semptomsuz olarak, toplumun \%30'unda bulunur. ${ }^{[1,2]}$ Neoplasm değildir ve WHO'ya göre gelişimsel bir anomalidir. Osteokartilajinöz eksositoza benzer şekilde, yoğun kemik gelişiminin olduğu metafizial bölgede ortaya çıkar. ${ }^{[5,6]}$ Bu lezyonun kemiğin çevresel büyümesi esnasında periosteumun yetersiz desteğinden mi yoksa epifız plağının altındaki enkondral ossifikasyonun oluşamamasından mı olduğu netlik kazanmamıştır. Semptom oluşturmadıklarından, hekime getiren sebep genellikle travmadır. ${ }^{[1,5]}$ Her iki lezyon da histopatolojik olarak aynıdır ve benign iğsi hücreli fibroblast ve histiositler, ayrıca az miktarda ksantomatik hücrelerden oluşurlar. ${ }^{[7]}$ Düz radyogram tanı için yeterlidir; histopatolojik inceleme gereksizdir ("Don't touch lesions!') (Şekil 1). ${ }^{[3]}$

Bu lezyonların biyolojik aktif dönemden involüsyona geçiş safhasındaki farklılıklar ve hatta lezyon içerisinin, histolojinin tersine, kemikle dolması tanıda zorluk çıkarabilir. Ritschl ve arkadaşları bu durumu dört dönemle tanımlamıştır. ${ }^{[5]}$
Fibrous cortical defects and non-ossifying fibromas constitute the most common focal lesions of bones..$^{[1,2]}$ Due to their benign character and typical radiological appearance, they belong to a group of lesions that do not require histopathological sampling for diagnosis ("Don't touch lesions!"). ${ }^{[3]}$ Despite this fact, their detection in radiological examination with surprising frequency causes unjustified concern, and leads to consultations in orthopaedic oncology clinics. ${ }^{[4]}$ It seems that this may be due to the variability of their presentations related to age and evolution of the lesions.

Key words: fibrous tissue neoplasms; cortical dysplasia; fibroma, ossifying

Evre A: Küçük, oval ve büyüme plağına komşu lezyon.

Evre B: Kemiğin büyümesi ile lezyon metafize ilerler, büyür, daha polisiklik bir görünüm ve üzüm salkımı şeklini alır.

Evre C: İçi kemik dokusu ile dolmağa başlar, mineralizasyon şafttan büyüme plağına doğru olur.

Evre D: Lezyonun tamamen kemikleşip kemik adacı̆̆ı halini almasıdır.

Bu evreler yaşla doğru orantılıdır.

NOF, FKD, fibroksantoma ve daha az olarak benign fibröz histiositoma (BFH) birbirleri ile radyolojik olarak eş anlamlı kullanılırlar. Ancak doğal yapısı ve ölçütleri göz önüne alındığında NOF ve FKD iki farkI lezyon olarak değerlendirilir. Fibroksantoma, patolojik özelliklerinden dolayı NOF yerine kullanılır. FKD için literatürde "metafizyel fibröz defekt", "metafizyel suprakondiler defekt" ve "gelişimsel defekt" isimleri de kullanılmıştır (Şekil 2). ${ }^{[8-11]}$

FKD'nin, "kortikal avulsif travma", "subperiosteal veya periosteal desmoid", "periostitis ossifikansın bir değişkeni" veya "kortikal desmoid" şeklinde yanlış olarak adlandırıldığı da olmuştur. "Kortikal desmoid ya da

- Illetişim adresi: Prof. Dr. Kaan Erler, Anadolu Sağlık Merkezi Hastanesi, Ortopedi ve Ortopedik Onkoloji Bölümü, Gebze, Kocaeli Tel: 0262 - 6785000 e-posta: drkaanerler@yahoo.com

- Geliș tarihi: 27 Eylül 2013 Kabul tarihi: 27 Ey/ül 2013 


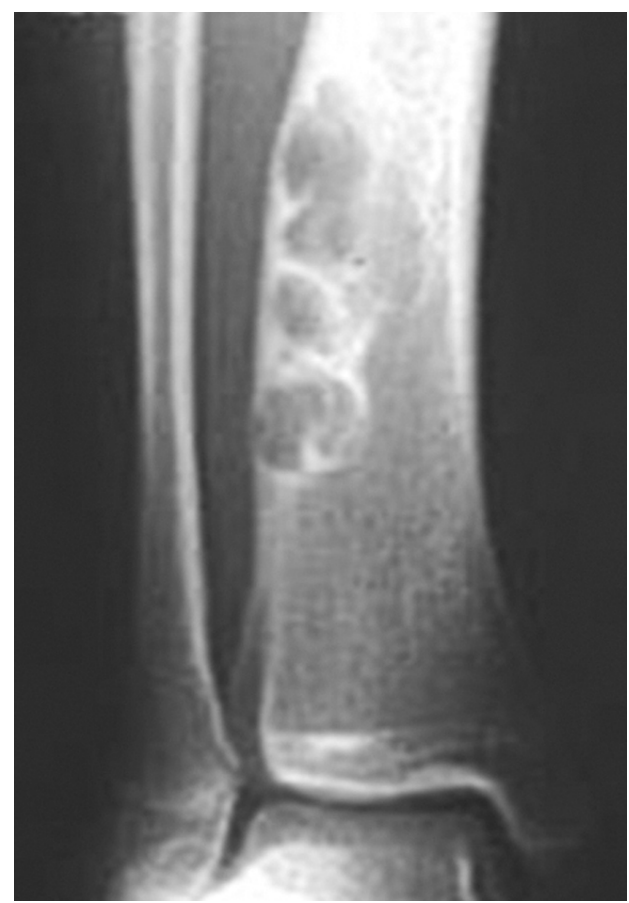

Şekil 1. Tibia distali non-ossifying fibroma.

"kortikal avulsif travma" isimlerinden de anlaşılacağı gibi, distal femur linea aspera boyunca tekrarlayan streslere bağlı olarak parça ayrılmasına bağlı bir kortikal defekttir. ${ }^{[12]}$

NOF ve FKD kemiğin saldırgan olmayan (nonagressive) lezyonlarıdır; ikisi arasında ölçü ve doğal yerleşimlerine göre bir ayrım yapılabilir. Her ikisi de gelişimsel defekt olarak değerlendirilir. Illk kez Lichtenstein ve Jaffe tarafından 1942'de tanımlanmıştır. ${ }^{[12]}$ FKD, 3 cm'den küçük, asemptomatik, küçük eksentrik yerleşimli, metafizyel kortikal defekt olup, bunların çoğu kendiliğinden kaybolabilir. Ancak bazıları büyür ve NOF'a benzer. Bu lezyonlar $3 \mathrm{~cm}$ 'den büyük, komşu kortekse doğru büyüme gösteren, eksentrik, kortekse dayanmış intramedüller yerleşim gösterir. Her iki lezyon da merkezi geçirgen (lusent) fibröz doku komponentini reaktif kemik ile doldurarak kendiliğinden geçebileceği gibi, bazıları lokal gelişmedeki farklılaşmalara bağlı hücresel çoğalmaya, ikincil olarak da erişkin çağa kadar büyümeğe devam eder, ağrı ve patolojik kırık oluşturma riski taşır. ${ }^{[13,14]}$ Tibia anteriorunda lokalize uzun lezyonlar olan amenoblastoma ve ossifying fibroma'dan ayrımına dikkat edilmelidir.

\section{Klinik}

FKD tipik olarak asemptomatiktir ve rastlantısal olarak, başka nedenlerden dolayı çekilen radyolojik

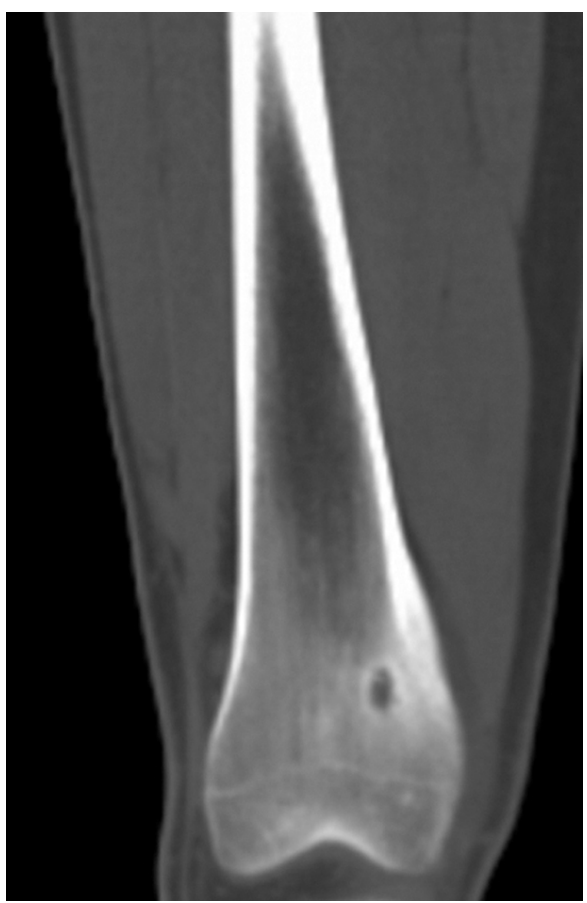

Şekil 2. Distal femurun bilgisayarlı tomografisinde, kortekste soliter geçirgen (lusent) lezyon görülmektedir.

incelemelerde ortaya çıkabilir. NOF da asemptomatiktir, ancak büyük lezyonlarda hafif ağrı radyolojik olarak tespit edilemeyen mikrokırıklar oluştuğunda görülebilir. Bazen hasta patolojik kırıkla da gelebilir. ${ }^{[15]}$ Çoğunluğu tek (soliter) lezyon olmalarına karşın nörofibromatozisli hastalarda \%5 multipl NOF saptanmıştır. İskelet dışı doğumsal anomaliler (café-au-lait lekeleri, mental retardasyon, hipogonadism, oküler anormallik, kardiovasküler malformasyonlar gibi) multipl NOF ile seyreder ve ilk kez 1983 yılında bildirilen Jaffe-Campanacci sendomunu oluşturur. ${ }^{[16,17]}$

\section{Radyoloji}

Düz radyogram hem NOF hem de FKD için tanısal değer taşır. Eğer görüntüde, boyutlarda ya da yaş ile ilgili bir uyumsuzluk varsa genellikle bilgisayarlı tomografi (BT) ve manyetik rezonans (MR) görüntülemeden faydalanılabilir. ${ }^{[18-21]}$ Düz radyogram tanısal olmasına karşın ayırıcı tanıda kondromiksoid fibrom (KMF) ve fibröz displazi (FD) özellikle çok yerleşimli (poliostatik), daha merkezi ve unilateral yerleşimli, ayrıca buzlu cam görünümlüdür. Osteoid osteoma (OO)'nın tipik çekirdeği (nidus) vardır; ayrıca "kemik absesi", "periosteal kondroma" ve "desmoplastik fibrom" ayrımı da yapılmalıdır.

"Yumuşak doku desmoidi" veya "kemiğin desmoplastik fibromu" biyopside bakılınca belli olabilir. Daha 
nadir olmasına karşın, "dev hücreli tümör”, “anevrizmal kemik kisti” büyük lobule NOF görüldügünde ayırıcı tanıda akla gelmelidir. Her iki lezyonun da BT veya MR ile net olarak ayrımı yapılır.

Kortikal avulsif travma (KAT) erişkinlerde daha çok gözlenir. FKD ile karıştırılır. Histolojik incelemede, KAT'ta sağlıklı osteoblastlar ve kemik spikülleri ile karışmış nonspesifik fibröz doku görünümü vardır. Genellikle tendonun distal femurda kemiğe yapıştığı yerdeki tekrarlayan travmalar sonucunda kortekste oluşturduğu avulsiyona bağlı olup, FKD'deki gerçek defektten farklıdır.

\section{Düz radyogram}

NOF'un görüntülenme özellikleri tanısaldır. Metadiyafiziyel, eksentrik, ovoid ya da dairesel yerleşimde, intramedüller jeografik radyolusensi keskin, sklerotik reaktif kemik ile sınırlıdır. Medüller sınır korteks sınırından daha kalın görünür. Genellikle başlangıçta epifiziyel komşuluğunda iken normal büyüme patternini izleyerek diyafize doğru ilerler. Epifiz etkilenmez. Daha büyük lezyonlar korteksin endosteal yüzeyini erozyona uğratarak 4-6 cm boyutlarında multiloküle görülür (Şekil 3 a). ${ }^{[9,20-22]}$

NOF'un, FKD'den oluştuğu düşünülür. Tipik FKD'ye benzer ve küçüktür, genellikle yuvarlak ya da ovoid şekilde, 1-3 cm büyüklügündedir. Distal femoral korteks posteromediyalinde, mediyal suprakondiler çıkıntı boyunca adduktor tüberkülün proksimalinde yerleşim gösterir. Lezyonun medüller kaviteye baskı yaptığı noktada keskin sınırı reaktif kemik görülür.Yumuşak doku komponenti yoktur. En iyi görüntü anteroposterior (AP) düz radyogramda, $20-40^{\circ}$ oblik dış rotasyonda ortaya çıkar (Şekil 3 b, c).

Genelde bu lezyonlar tübüler kemiklerde eksentrik yerleşim göstermesine karşın, fibula bunun tek istisnası olup tüm kemik çapını tutabilir; bu da tanıda zorluklar yaratabilir. NOF yavaş büyüyen bir lezyondur. Ölçütlerindeki ve yoğunluğundaki değişimler lezyonların doğal rezolüsyonu ve ara büyümelerine ikincil gelişir. Bunlar zaman içerisinde merkezi lusent defekti dolduran ve yerine geçen reaktif kemik formasyonunu içerir. ${ }^{[9,11,22]}$

Bu sklerozdaki ilerleyici değişimin erken aşamaları, gözlemciler tarafindan FD yanlış yorumununa neden olabilir. Hatta tipik lokalizasyon ve geçiş süreci bilinmez ise neoplastik lezyonlar karıştırabilir. Periosteal reaksiyon sadece patolojik kırık durumunda söz konusudur. Bu saldırgan olmayan fibröz lezyonların karakteristik özellikleri ve yerleşim yerleri, ayrıca zaman içerisindeki dönüşümleri iyi bilinirse, tanıda nadiren hata yapılır. Ancak çok atipik olgularda ileri radyolojik görüntülemeye gereksinim duyulur.

Distal posteromediyal femurun KAT'si sıklıkla FKD ile karışır. Genellikle KAT daha çok kortikal düzensizliğe
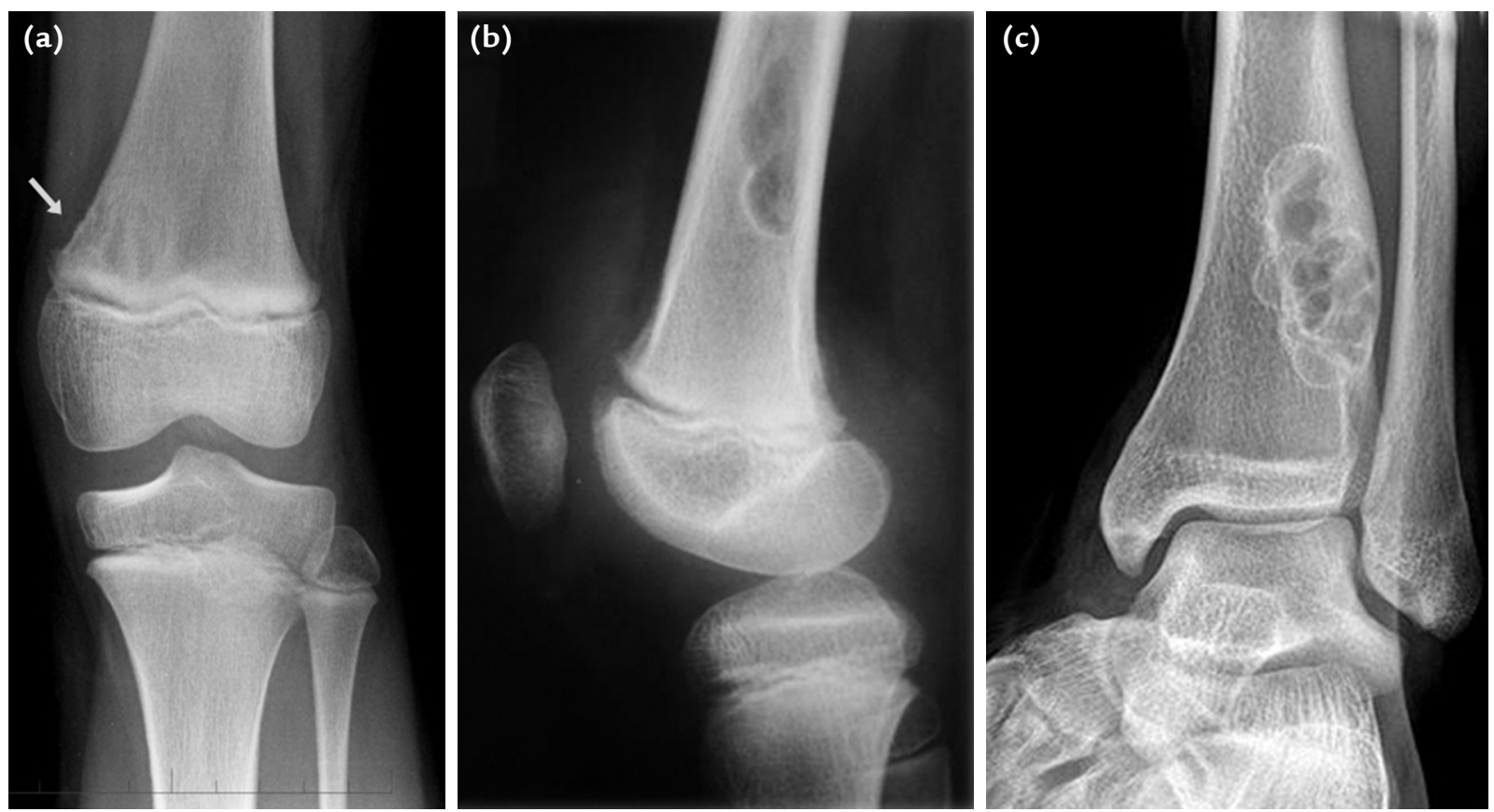

Şekil 3. a-c. Distal femur AP düz radyogramda kortikal, radyolusent soliter lezyon FKD ile uyumludur (a). Oblik (45'lik) radyogram en iyi görüntülemeyi sağlar. Hiçbir yumuşak doku ve periosteal reaksiyon mevcut değildir (b). Tibia distalinde eksentrik yerleşimli lobüle NOF. Periferik sklerotik sınır ile merkezi lusensi lezyon için tipik görünüm oluşturur (c). 
sahiptir ve direkt gastroknemius kasının yapışma yerinde bulunur. Genç atletlerde görülür.

\section{BT}

Atipik bir lezyon ve klinik tablo görülmedikçe ilerli görüntüleme yapmağa gerek yoktur. Karakteristik lezyon; eksentrik yerleşimli, intramedüller, iyi sınırlı merkezi lusent ve sklerotiktir. Lusensi heterojen ve reaktif skleroz, ileri evrelerde değişkenlik gösteren NOF'de görülür. Eski lezyonlarda reaktif kemik bileşkesine karşı daha anlamlı yumuşak doku tutulum vardır. BT görüntüler, patolojik kırı̆ga neden olabilecek aksiyel kesit kemik tutulumu ve kortikal incelme derecesini belirlemede yararlıdır (Şekil $4 \mathrm{a}, \mathrm{b}$ ).

Yayınlar, tübüler kemiğin genişliğinin \%50'den fazlasının tutulumu ve 33 mm'den daha fazla NOF yayılımında yüksek kırık riski olduğunu belirtir. Eğer kırık oluşur ise hafif yumuşak doku ödemi ile periost reaksiyonu görülebilir. ${ }^{[11,18]}$

Her iki lezyon da çok karakteristiktir ve $\% 99$ güvenirlilik vardır. FKD'de lezyonlar erken dönemde çok küçük olduğu için, kortikal sınııın hafif kalınlaşması yine hafif merkezi kortikal lusensi ile görülür. BT, düzensiz avulsif travmaların ayııımını sağlayabilir. Erken dönemde adduktor magnus kası ile gastroknemius kasının mediyal başı arasındaki baskı travmalarının ortaya koyulması ve kortikal defekt belirlenmesinde yardımcı olur. Böylece biyopsiye gerek kalmaz. Yalancı pozitif bulgular çok küçük kortikal avulsif düzensizlikleri içerir. Küçük kortikal OO, eğer kesitler çok ince ve nidus görülemez ise FKD ile karışabilir, ancak klinik tabloda ağrı olması OO lehinedir.
MR

Genellikle hem NOF hem de FKD rastlantısal olarak ortaya çıkar ve aslında görüntüleme başka nedenlerden dolayı yapılmıştır. T1- ve T2-ağırlıklıklı Spin-echo MR'de düşük yoğunlukta görülmeleri karakteristiktir. ${ }^{[19]}$ Bu bulgu diğer nonossifiye lezyonlar için de geçerlidir. T2-ağırlıklı görüntülerdeki düşük yoğunluğun fibröz doku içerinde bulunan büyük miktarlardaki kollajen ya da hemosiderine ait olabileceği düşünülmüştür (Şekil $5 \mathrm{a}, \mathrm{b}$ ).

Ödem ve kortikal düzensizlik yoktur. MR bu lezyonların tanımlanmasında sıklıkla kullanılmadığından ayrıntıIı bilgi bulunmamaktadır. MR'deki güvenirlilik \%95 civarındadır. Periferik düşük yuğunluktaki sınır, düz radyogramda görülen kenar sklerozunu gösterir ve histolojik değerlendirmede periferik reaktif skleroz vardır. Parlak alanlar yeterli hücresel yoğunlukla beraber görülür. ${ }^{[19]}$

FKD için genellikle MR istenmez. Ancak intrakortikal lezyonda, T1'de düşük sinyal, proton yoğunluğu ve T2'de artan sinyal yoğunluğunda olması heterojen fibröz histolojik özelliğindendir. Düşük sinyal yoğunluğu, medüller kanal ve kortikal sınıra yaslanmış sklerotik sınırı gösterir.

\section{Sintigrafi}

İyi huylu kemik lezyonunun göstergesi olan hafiften orta dereceye değişen tutulum (ör., technetium-99m [ ${ }^{99 \mathrm{~m} T c]}$ ), aktif kemik lezyonlarındaki aktivasyondan çok daha azdır.

Çocuk ya da adolesanda, tübüler kemiğin epifize yakın alanda eksentrik tutulum bölgesi, NOF için
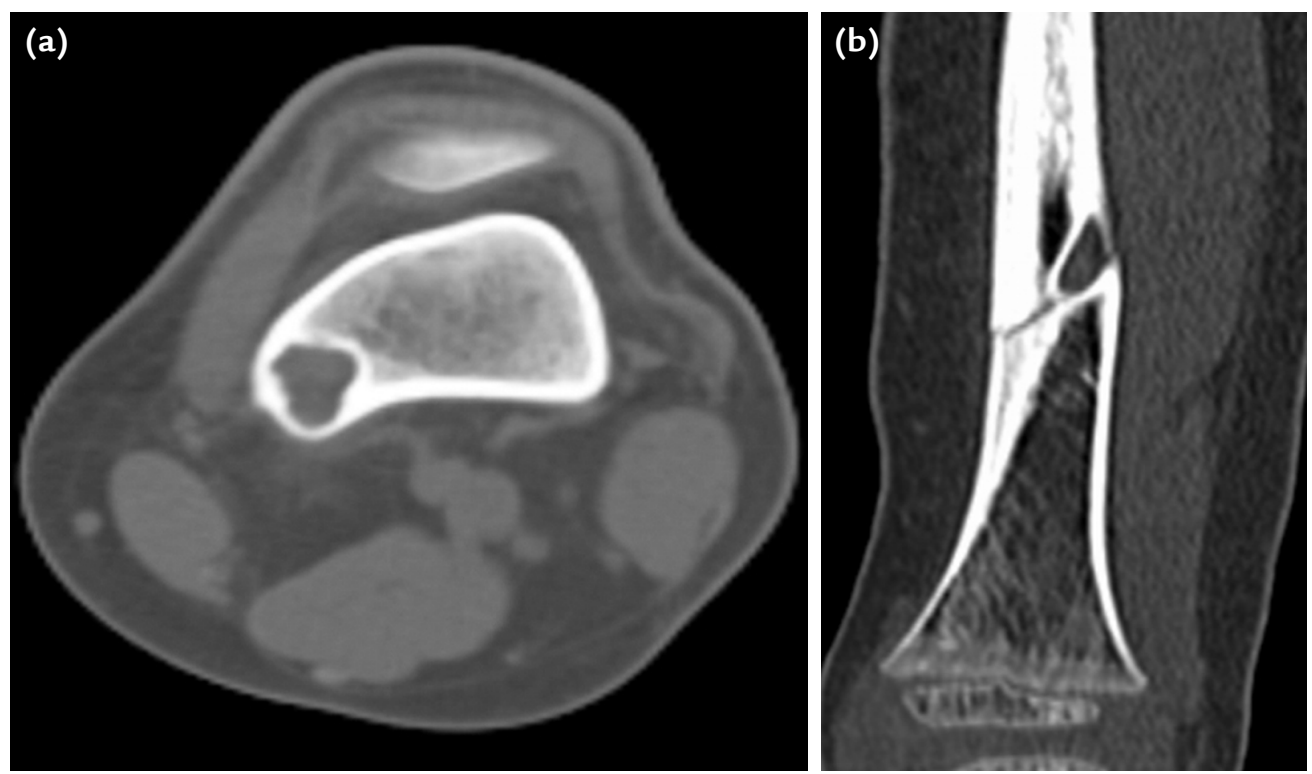

Şekil 4. a, b. Femur distali NOF (a). Tibia distali FKD, patolojik kırık ile beraber (b). 

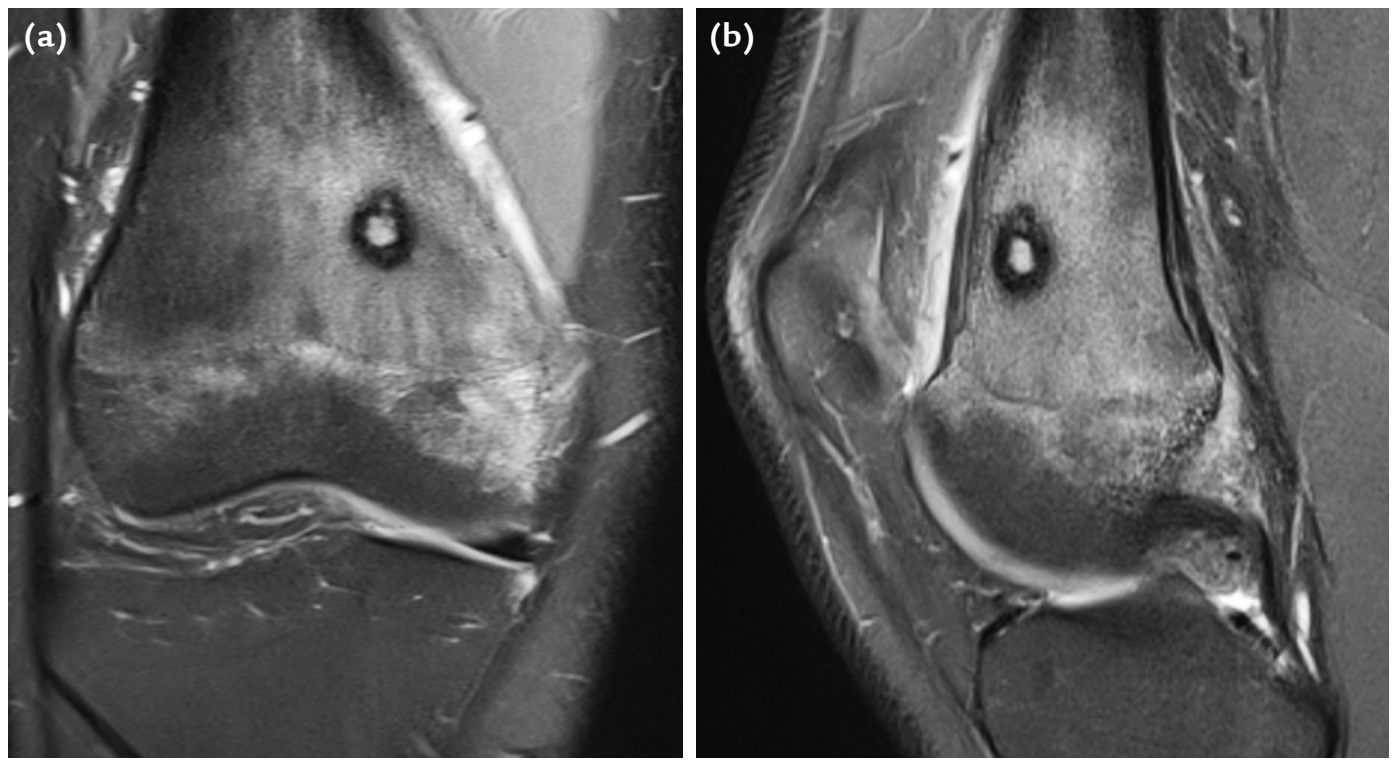

Şekil 5. a, b. Distal femurdaki FKD'nin koronal proton yoğunluğundaki MR görüntüsü, periferik sınırda düşük yoğunluk, intrakortikal merkezde orta dercede yoğunluk gösterir (a). Distal femur FKD sagittal T2ağırlıklı MR, merkezde heterojen orta derecede ve sınırları düşük sinyal yoğunluğunda görülür (b).

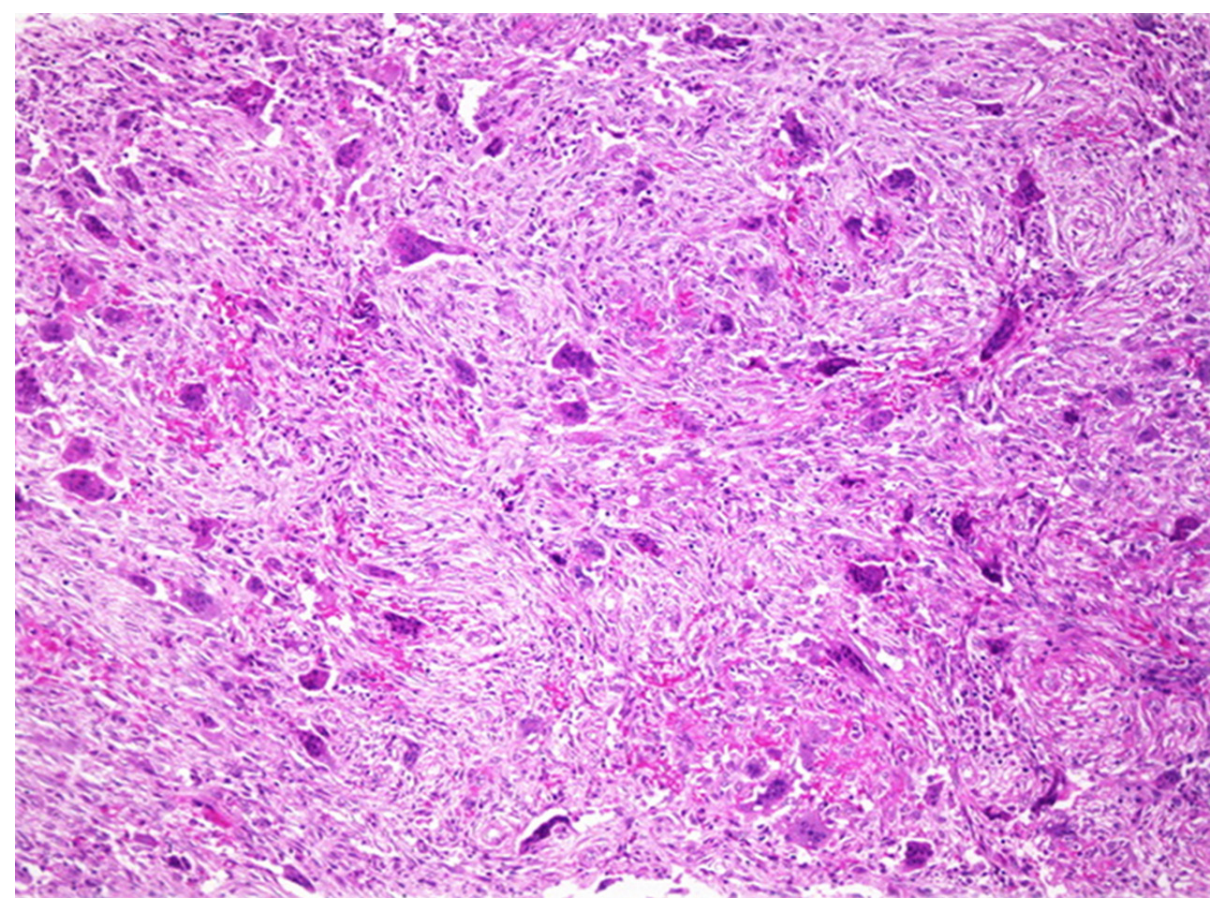

Şekil 6. NOF mikroskopik görünüm.

tanısaldır. FKD sintigrafide tutulum yoktur. Çocukluk çağında epifiz plağının kanlanmasına bağlı tutulum bu durumu maskeler. ${ }^{[12,23,24]}$

Kortikal avulsif düzensizlikte, FKD lokalizasyonunda olduğundan daha fazla tutulum gözlenir. Özellikle osteosarkomanın periosteal yerleşimli tipinde, erken dönemde distal femur posteriorunda tutulum vardır; radyolojik korrelasyon ayıııcı tanıyı sağlar.

\section{Histoloji}

Kemik oluşumun gerçekleşemediği bir alanı kapsar. Bu bölgede fibröz bağ dokusu ve aralarında çok çekirdekli dev hücreler bulunur. Dev hücreler destek dokusundan oluşmaz ve fagositik özellikleri yoktur. Lezyonda ince kenarlı reaktif kemik sınırı vardır. Mikroskopik olarak bu reaktif kabukta yeni kortikal kemiğin lamella ve trabekulasını döşeyen osteobastlar görülür (Şekil 6). ${ }^{[25]}$ 


\section{KAYNAKLAR}

1. Caffey J. On fibrous defects in cortical walls of growing tubular bones: Their radiologic appearance, structure, prevalence, natural course, and diagnostic significance. Adv Pediatr 1955;7:13-51.

2. Dehner LP. Juvenile xanthogranulomas in the first two decades of live: a clinicopathologic study of 174 cases with cutaneous and extracutaneous manifestations. Am J Surg Pathol 2003;27(5):579-93.

3. Helms CA. Fundamentals of Skeletal Radiology. 3rd ed. Elsevier Saunders; 2004.

4. Stacy GS, Dixon LB. Pitfalls in MR image interpretation prompting refferals to an orthopedic oncology clinic. Radiographics 2007;27(3):805-26.

5. Ritschl P, Karnel F, Hajek P. Fibrous metaphyseal defects - determination of their origin and natural history using radiomorphological study. Skeletal Radiol 1988;17(1):8-15.

6. Fletcher CDM, Unni KK, Mertens F, editors. World Health Organization Classification of Tumours. Pathology and Genetics of Tumours of Soft Tissue and Bone. Lyon: IARC Press; 2002. p.225-26.

7. Greenspan A, Jundt G, Remagen W. Diagnostyka różnicowa w onkologii ortopedycznej. Medipage, Warszawa. 2008:269-78.

8. Moser RP Jr, Sweet DE, Haseman DB, Madewell JE. Multiple skeletal fibroxanthomas: radiologic-pathologic correlation of 72 cases. Skeletal Radiol 1987;16(5):353-9.

9. Betsy M, Kupersmith LM, Springfield DS. Metaphyseal fibrous defects. J Am Acad Orthop Surg 2004;12(2):89-95.

10. Wootton-Gorges SL. MR imaging of primary bone tumors and tumor-like conditions in children. Magn Reson Imaging Clin N Am 2009;17(3):469-87. CrossRef

11. Demiralp B, Kose O, Oguz E, Sanal T, Ozcan A, Sehirlioglu A. Benign fibrous histiocytoma of the lumbar vertebrae. Skeletal Radiol 2009;38(2):187-91. CrossRef

12. Bufkin WJ. The avulsive cortical irregularity. Am J Roentgenol Radium Ther Nucl Med 1971;112(3):487-92.

13. Jaffe HL, Lichtenstein L. Solitary unicameral bone cyst with emphasis on the roentgen picture, the pathologic appearance and the pathogenesis. Arch Surg 1942;44:1004-25.
14. Steiner GC. Fibrous cortical defect and nonossifying fibroma of bone. A study of the ultrastructure. Arch Pathol 1974;97(4):205-10.

15. Arata MA, Peterson HA, Dahlin DC. Pathological fractures through non-ossifying fibromas. Review of the Mayo Clinic experience. J Bone Joint Surg Am 1981;63(6):980-8.

16. Campanacci M, Laus M, Boriani S. Multiple non-ossifying fibromata with extraskeletal anomalies: a new syndrome? J Bone Joint Surg Br 1983;65(5):627-32.

17. Mirra JM, Gold RH, Rand F. Disseminated nonossifying fibromas in association with café-au-lait spots (JaffeCampanacci syndrome). Clin Orthop Relat Res 1982;(168):192-205.

18. Jee WH, Choe BY, Kang HS, Suh KJ, Suh JS, Ryu KN, Lee YS, Ok IY, Kim JM, Choi KH, Shinn KS. Nonossifying fibroma: characteristics at MR imaging with pathologic correlation. Radiology 1998;209(1):197-202.

19. KransdorfMJ, UtzJA, GilkeyFW, Berrey BH. MR appearance of fibroxanthoma. J Comput Assist Tomogr 1988;12(4):612-5.

20. Resnick D, Greenway G. Distal femoral cortical defects, irregularities, and excavations. Radiology 1982;143(2):345-54.

21. Resnick D, Kyriakos M, Greenway GD. Tumors and tumor-like lesions of bone: imaging and pathology of specific lesions. In: Resnick D, editor. Diagnosis of Bone and Joint Disorders. 3rd ed. Philadelphia: WB Saunders; 1995. p.3628-938.

22. Lee SH, Baek JR, Han SB, Park SW. Stress fractures of the femoral diaphysis in children: a report of 5 cases and review of literature. J Pediatr Orthop 2005;25(6):734-8.

23. Burrows PE, Greenberg ID, Reed $\mathrm{MH}$. The distal femoral defect: technetium-99m pyrophosphate bone scan results. J Can Assoc Radiol 1982;33(2):91-3.

24. Hod N, Levi Y, Fire G, Cohen I, Ayash D, Somekh M. Scintigraphic characteristics of non-ossifying fibroma in military recruits undergoing bone scintigraphy for suspected stress fractures and lower limb pains. Nucl Med Commun 2007;28(1):25-33.

25. Enneking WF. Benign Skeletal Lesions, Nonossifying Fibroma. In: Enneking WF, editor. Clinical Musculoskeleteal Pathology. Rev. 3rd ed. Gainesville, FL: University of Florida Press; 1990. p.302-6. 